\author{
Research Article
}

\title{
VRIKSHAYURVED METHODS FOR DISEASE CONTROL IN PLANTS WITH SPECIAL REFERENCE TO ONION (ALLIUM CEPA)
}

\section{More Shweta Vinod1*, Avalaskar Amit D², Mahajan Vijay3 ${ }^{3}$, Sogam Onkar Anant ${ }^{4}$}

${ }^{*}$ PG Scholar, ${ }^{2}$ Associate Professor, Department of Dravyaguna vigyan, Sumatibhai Shah Ayurved Mahavidyalaya, Pune, Maharashtra, India.

3 Principal Scientist (Hort.), ${ }^{4}$ Young Profession II, ICAR-DOGR, Rajgurunagar, Pune, India.

\begin{tabular}{l} 
Article info \\
\hline Article History: \\
Received: 03-08-2021 \\
Revised : 25-08-2021 \\
Accepted: 03-09-2021 \\
Published: 18-09-2021 \\
\hline KEYWORDS: \\
Vrikshayurved, \\
Plant diseases \\
(Vyadhi), Vata- \\
Pittaj Vyadhi (plant \\
disease), Kunap Jal, \\
Madhuyastyadi \\
Kwatha
\end{tabular}

\section{INTRODUCTION}

Ayurveda Science deals with various branches, it mainly divided into 3 branches, (1)

- Vrukshayurved (Plant science)

- Pashuayurved (Animal Science)

- Manushyayurved (Human Science)

In that, Vrikshayurved (plant science) were introduced by Sage Parashar (c.400 BC) wrote KrishiParashar tantra which is considered as the first written document on agriculture or on plant life.(2)

\begin{tabular}{|l|l|}
\hline \multicolumn{3}{|c|}{ Access this article online } \\
\hline Quick Response Code & \begin{tabular}{l} 
https://doi.org/10.47070/ijapr.v9i8.2041 \\
\hline
\end{tabular} \\
\hline
\end{tabular}

Vrikshayurved mainly emphasis on seed collection, storage, sowing, weeding, irrigation, draining, harvesting, land preparation and plant diseases. Further references were found in various texts like Kautilya artha shastra, Agnipuran, Vrikshayurved by Surpala, Bruhat samita by Varamihir, Upavan Vinod by Sarangdhar, All textbooks of plant pathology gives credit to the French botanist, Turnefort (1705 AD) for classifying plant diseases into 2 types which is internal and external but In Vrikshayurved by Surpala (c. 1000AD) it's been already mentioned as Abhyantar Vyadhi (internal diseases) and Bahya vyadhi (external diseases). Unlike human being plant diseases also classifieds as a 1. Abhyantar Vyadhi (internal diseases) in which they further divided as Vataj, Pittaj and Kaphaj 2. Bahay (external diseases) due to insects and cold weather.(3) So, in current era of civilization need of an hour to re-evaluate our own science to treating plants and harvesting chemical free 
or organic plant which can be more potent to treat

human diseases.

\section{MATERIALS AND METHODS}

\section{Materials}

Study Material- Onion (Allium cepa) seedlings

Study Place- Directorate of Onion and Garlic Research Centre, Rajgurunagar

\section{Treatment Material}

1. Kunap Jal

2. Madhuyastyadi Kwath

Table 1: Materials for Kunap Jala [4]

\begin{tabular}{|c|l|l|}
\hline Sr.No. & Materials & Quantity \\
\hline 1 & Flesh, fat, bone marrow of the goat / sheep & $1 \mathrm{~kg}$ \\
\hline 2 & $\begin{array}{l}\text { Water for boiling (Tanumamsarasa ref } \\
\text { Sharangdhar) }\end{array}$ & 32 lit. /As per requirement \\
\hline 3 & Masha (Black gram) & $125 \mathrm{gm}$ \\
\hline 4 & Krushana Tila (Sesamum) & $62.5 \mathrm{gm}$ \\
\hline 5 & $\begin{array}{l}\text { Chana dal (Bengal gram split), Moong dal (Green } \\
\text { gram split), Tuwar dal (pigeon peas) }\end{array}$ & $31.25 \mathrm{gm}$ each \\
\hline 6 & Madhu (Honey) & $25 \mathrm{gm}$ \\
\hline 7 & Go Ghrita & $25 \mathrm{gm}$ \\
\hline 8 & Go Dugdha (Milk) & $250 \mathrm{ml}$ \\
\hline
\end{tabular}

Table 2: Materials for Madhuyasthyadhi Kwath(5)

\begin{tabular}{|l|l|}
\hline Materials & Quantity \\
\hline Yasthimadhu Powder (Glycyrrhiza glabra) & $125 \mathrm{gm}$ \\
\hline Madhuk Powder (Madhuca indica) & $125 \mathrm{gm}$ \\
\hline Madhu (Honey) & $6.25 \mathrm{gm}$ \\
\hline Go Ghrita (Cow's ghee) & $6.25 \mathrm{gm}$ \\
\hline Go Dugdha (Cow milk) & $60 \mathrm{ml} /$ appx \\
\hline Water & 8 lit. /As per requirement \\
\hline
\end{tabular}

\section{Methods}

1. Diagnosis / Identification of disease on Onion seedlings according to Vrikshayurved.

2. Preparations of Kunapl Jal and Madhuyastyadi Kwath for treatment.

At starting seedlings was normal and healthy right from germination to one month old. There growth was steady, around 3-4cm per week.

On $35^{\text {th }}$ day, yellowish discoloration and curling of leaves at tip region were observed in onion seedlings first. Few days later, seedlings turned dry.

These findings were compared with Vrikshayurved disease diagnostic methods and diagnosis was confirmed. Then accordingly treatment was decided. 
Table 3: Diagnosis/ Identification of Vruksha Vyadhi (Plant disease) \& its treatment according to Vrikshayurved

\begin{tabular}{|c|c|c|c|c|}
\hline Sr. No & Condition & $\begin{array}{l}\text { Causes/ } \\
\text { Reason(6) }\end{array}$ & Sign \& Symptoms ${ }^{(6)}$ & Treatment(7) \\
\hline 1 & Vataj & $\begin{array}{l}\text { a) The land that } \\
\text { becomes arid } \\
\text { on account of } \\
\text { excessive } \\
\text { supply of dry } \\
\text { and pungent } \\
\text { matter. }\end{array}$ & $\begin{array}{l}\text { a) Karshyata (Thinning/ } \\
\text { Atrophy of leaves, trunk, } \\
\text { stem, branches. } \\
\text { b) Granthi (Glandular } \\
\text { formations on fruits and } \\
\text { leaves. } \\
\text { c) Gutikaarudha Patra } \\
\text { (curling/ pipe formation of } \\
\text { leaves. } \\
\text { d) Karkashatva (roughness of } \\
\text { parts). } \\
\text { e) Aswadhuphalata } \\
\text { (Deficiency in pulp/ juice, } \\
\text { distastefulness of fruits. } \\
\end{array}$ & $\begin{array}{l}\text { a) Mamsa (flesh), Meda } \\
\text { (fat), Ghruta (ghee) } \\
\text { Should give to plants. } \\
\text { b) Kunap Jal (fermented } \\
\text { fertilizer) -Made with } \\
\text { flesh of goat, Mash (black } \\
\text { gram), Krushna Tila (black } \\
\text { seasme), Tuwar Dal } \\
\text { (pigeon peas), Moong Dal } \\
\text { (green gram split), Chana } \\
\text { Dal (bengal gram split), } \\
\text { honey, Desi Gir cow milk } \\
\text { and Ghee, water. }\end{array}$ \\
\hline 2 & Pittaj & $\begin{array}{l}\text { a) Due to } \\
\text { summer } \\
\text { season. } \\
\text { b) Excessively } \\
\text { watered with } \\
\text { bitter, sour, } \\
\text { salty } \\
\text { materials }\end{array}$ & $\begin{array}{l}\text { a) Pitapatrata (yellowness of } \\
\text { leaves). } \\
\text { b) Padavishoshana (drying of } \\
\text { plant). } \\
\text { c) Phalastrav (drooping of } \\
\text { fruits). } \\
\text { d) Patra/ Pushpa/Phala } \\
\text { mlanavta (leaves / flower/ } \\
\text { fruit loosing natural } \\
\text { appearance) }\end{array}$ & $\begin{array}{l}\text { a) Madhuyastyadi Kwath- } \\
\text { Yastimadhu (Glycyrrhiza } \\
\text { glabra) powder, Madhuk } \\
\text { (Madhuca indica) powder, } \\
\text { honey, Desi Gir cow milk } \\
\text { and ghee, water } \\
\text { b) Phaladi Kwath Triphala } \\
\text { (Three myrobalan, viz. } \\
\text { Amalaki (Emblic officinalis), } \\
\text { Haritaki (Terminalia } \\
\text { Chebula), Bibhitaki } \\
\text { (Terminali bellirica), Ghee, } \\
\text { honey Water }\end{array}$ \\
\hline 3 & Kaphaj & $\begin{array}{l}\text { a) Occur in } \\
\text { winter and } \\
\text { spring. } \\
\text { b) Excessively } \\
\text { watered } \\
\text { with sweet, } \\
\text { oily, sour } \\
\text { and cold } \\
\text { materials. }\end{array}$ & $\begin{array}{l}\text { a) Atikalaphalata (late/ } \\
\text { delaying in fruiting). } \\
\text { b) Pandutva (paleness of } \\
\text { leaves, fruits etc). } \\
\text { c) Kubjata (dwarfing of } \\
\text { leaves). } \\
\text { d) Akalaphalita (fruiting not at } \\
\text { proper time). } \\
\text { e) Nirasata (tastelessness) }\end{array}$ & $\begin{array}{l}\text { a) Bruhatpanchamool } \\
\text { Kwath- Decoction made } \\
\text { from roots of five plant } \\
\text { species viz. Bilwa (Aegle } \\
\text { marmelos), Agnimantha } \\
\text { (Clerodendrum } \\
\text { phlomoides), Shyonak } \\
\text { (Oroxylum indicum), Patala } \\
\text { (Sterospermum } \\
\text { suaveloens), Gambhari } \\
\text { (Gmelina arborea). } \\
\text { b) Paste and Spray } \\
\text { i) Shwet Sarshap } \\
\text { Kalka (White mustard } \\
\text { paste application) - } \\
\text { Externally on roots. } \\
\text { ii) Tilabhuti Jala- } \\
\text { Ash of sesame seeds mixed } \\
\text { in water should be } \\
\text { sprayed. }\end{array}$ \\
\hline
\end{tabular}

Thus Onion seedlings had Vata- Pittaj plant diseases. (For reference table no 3)

According to the diagnosis Kunap Jal and Madhuyastyadi Kwath were selected as an intervention. 
Table 4: SOP for Kunap Jal

\section{SOP for Kunap Jala}

Prepare first Mamasarasa (meat soup) with Mamasa (meat) and water

Then add previously made Chana dal (bengal gram split), Moong dal (green gram split), Tuwar

dal (pigeon peas) and Krushana tila (black sesame) Kwath (decoction)

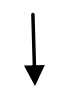

Cook Masha (black gram) in milk prepare sticky cake and add into above liquid material

Then add honey and milk in above liquid mixture and pour this into mud pot and place that mud pot in pit for 14 days, after that remove that pot and strain it the liquid material which obtained end of the procedure called as Kunap Jala

\section{Treatment- (Sop for preparation refer table 4, 5)}

1. Kunap Jal- Sprinkling of Kunap jal over Onion seedlings each group approximately $2 \mathrm{lt}$ once in week this is for curling of leaves, dryness and growth hampers due to excessive Vata Dosha in plants.

2. Madhuyastyadi Kwath- Decoction of Madhuyastyadi sprinkle over onion seedlings each group approximately 2lit once in week this for yellowing of leaves due to excessive Pitta dosha in plants.

\section{OBSERVATIONS (explain in table no 6).}

Observations were taken on $0,7 \& 14^{\text {th }}$ day. On the 0 day curling of leaves at tip region of onion leaves,
Table 5: SOP for Madhuyastyadi Kwath

\section{SOP for Madhuyastyadi Kwath}

Take Yastimadhu and Madhuk 1 part in coarse form

Add $16^{\text {th }}$ part of water in above coarse drug

Then reduce upto $1 / 8^{\text {th }}$ part

Cool it, strain it add honey, milk and Ghrita and use always freshly prepared. dryness of leaves, yellowish discoloration were moderate to severe. On the $7^{\text {th }}$ day, curling was reduced to some extent whereas yellowish discoloration of leaves, dryness of leaves was improved fairly. On the $14^{\text {th }}$ day, curling improved very much, dryness and yellowish discoloration were totally diminished.

Although seedlings were diseased, average growth rate was normal i.e., $3-4 \mathrm{~cm} /$ week. After intervention, growth rate was same for next week but it was doubled in further next week. Thus very rapid growth rate was observed.

Table 6: Study observation

\begin{tabular}{|l|l|l|l|l|}
\hline S.no & Observation & $\mathbf{0}$ day & $\mathbf{7}^{\text {th }}$ day & $\mathbf{1 4}^{\text {th }}$ day \\
\hline 1 & $\begin{array}{l}\text { Curling of leaves at tip region of } \\
\text { onion leaves }\end{array}$ & +++ & ++ & + \\
\hline 2 & Yellowish discoloration of leaves & ++ & + & 0 \\
\hline 3 & Dryness & +++ & + & 0 \\
\hline
\end{tabular}

(For mild symptoms ' + ', moderate ' ++ ', severe ' +++ ' and no symptoms '0') 

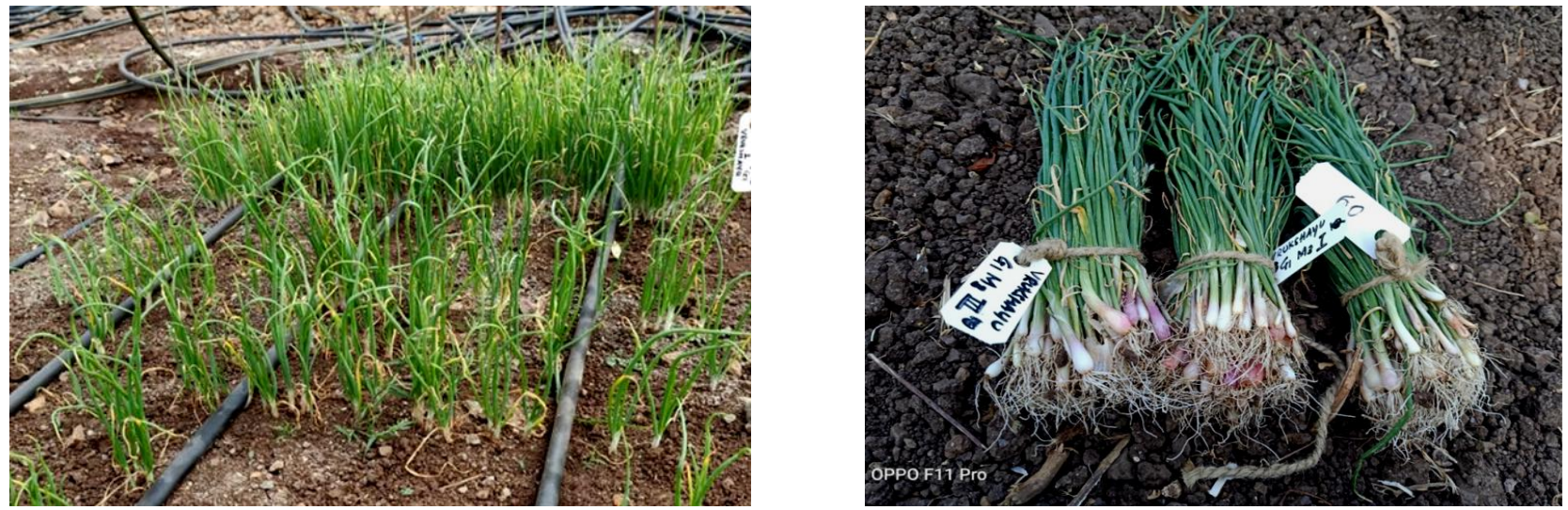

Before- Yellowing and curling of Onion seedling tip region
After treatment- Yellowish discoloration reduces completely plants look healthy also curling of tip also reduce moderately

\section{RESULTS}

1. Curling of leaves improved steadily from day 1 to day 14 . At $14^{\text {th }}$ day, minimal curling of leaves was observed.

2. Yellowish discoloration of leaves showed steady changes in recovery. Leaves became normal in second week.

3. Dryness of leaves improved very fast after intervention and leaves appeared an unctuous after 14 days.

4. The Vrikshayurved methods showed around 80$85 \%$ reduction in curling of leaves, $100 \%$ reduction in yellowish discoloration, 100\% reduction in dryness of leaves.

5. Vrikshayurved intervention improved growth rate drastically.

\section{DISCUSSION}

We need to confirm the relevance of our previous precious knowledge of Vrikshayurved (plant science) in today's era. So data was collected from ancient Vrikshayurved related Granthas like Atharvaveda, Kautilya Arthashastra, Agnipuran, Krushiparashar Tantra, Bruhat samhit by Varamihir, Vrikshayurved by Surpala, Upvan Vinod by Sarangdhar. Detailed methods to improve plant nutrition and to keep plants disease free were compiled. Kunap jal and Madhuyastyadi Kwath were used as intervention to treat Abhyantar Vyadhi (Internal diseases) of plant.

Normal Onion (Allium cepa) needs various nutrients for their growth - Nitrogen, Phosphorus, Potassium in more quantity whereas Sulphur, Iron, Calcium, and Zinc in minimal quantity. Due to the deficiency of NPK i.e. (Nitrogen, Phosphorus, Potassium) leaves become uniformly yellow ${ }^{(8)}$ (there may be so many reasons of yellowish discoloration in plant like, moisture stress, temperature changes, heavy manuring and absence of sunlight, but the most common reason in Onion seedlings is NPK deficiency) ${ }^{(9)}$ leaves get dried, dull and become smaller in size. Calcium and sulphur deficiency cause necrosis or curling of leaves(10) (there may be so many reasons for curling like due to excessive use of pesticides, overwatering, exposure to excessive sunlight, chemical damage, viral infection, and nutrient deficiency in onion seedlings is due to Nitrogen, Calcium and Sulphur deficiency)(11).

Vrikshayurved considers curling and dryness of leaves as a Vataj disease. Vata has predominance of Vayu and Aakash Mahabhutas ${ }^{(12)}$ so it is Ruksha (dry) in nature. When Vata increases in plant, leaves become dry. This Rukshta also leads Sankoch (contraction) in the plant tissues, so curling in plants were observed.

Vrikshayurved considers yellow discoloration of leaves as a Pittaj disease. Pitta has predominance of Agni Mahabuta so it is Ushana, Tikshna (tissue disturbing) in nature.(12) When Pitta increases in plant, it disturbs normal physiology of leaf tissue thereby reducing chlorophyll content and hampers nutrition of leaves then leaves become yellowish in color.

Kunap Jal was used as first intervention to combat Vataj diseases. So, it causes mild improvement in curling and yellowish discoloration but it shows marked improvement in dryness of leaves. As per modern science, It must have increased NPK, calcium and sulphur in optimum quantity in plant tissue of Onion seedlings the reason is still unknown.

Kunap Jala shows following pharmcodynamic effects.(13)

1. Aja mamsa (goat meat) has Rasa Madhur, Virya Natiushana, Vipak Madhur and Doshaghanta Tridoshshamak, Karma Bruhan also it comes under Aagrey sangraha "Mamsam Bruhananam"(14) 2) Cow's milk (Godugdha) shows Rasa Madhur, Virya Sheeta, Vipak Madhur, Guna Guru-Snighdha, Karma Jivaniya (enlivening), Bruhan, Balya (strengthening) and Doshaghanta reduces Vata-Pitta and alleviate Kapha Dosha.

2. Honey (Madhu) shows Rasa Madhur, Kashaya, Virya Ushana, Vipak Madhur, Guna Laghu Ruksha it pacifies alleviated Kapha Dosha and increases VataPitta Dosha. 
3. Sesame (Krushana Tila) shows Rasa Madhur, Kashaya \& Tikta, Virya Ushana, Vipak Madhur, Guna Laghu Ruksha, Doshaghanta Vata Kaphahara and Pittakara.

4. Black gram (Masha) shows Rasa Madhur, Virya Ushana, Vipak Madhur, Guna Guru- Snigdha, Doshaghanta increases Kapha-Pitta and decreases Vata, Karma Bruhan, Balya (improves strength).

5. Moong Dal (split green gram) Rasa Kashay, Madhur, Virya Sheeta, Vipak Madhur, Guna Laghu- Ruksha, Doshaghanta decreases Kapha-Pitta. All the materials in Kunap Jal contain mostly Rasa Madhur, Guna Guru-Snigdha, Virya Sheeta, Vipak Madhur and also shows Balya, Bruhaniya Karma i.e. gives strength.

6. All these Dravyas are Vata Shamak in nature (to pacify the aggravated Vata) so useful in Vataj disease.

7. These Dravyas are processed together to form Kunap Jala. The resultant Kunap Jala becomes separate Dravya and it may show different efficacy than individual Dravyas (Ref- "Samyogvat Prabhav" by Aacharya Chakrapani).

\section{According to modern point of view}

1. Meat having rich properties with high contain of Proteins, phosphorus, triglycerides, phospholipids, vitamins $A, D$ and $E$ (15).

2. Cow's milk is rich in Proteins ( $40 \%$ total amino acids), calcium it provides nutrient values to plant, fats also in a recent report claimed that milk sprays induced systemically acquired resistance in curling of leaves, a viral disease. (16).

3. Honey is rich in Calcium, potassium, phosphorus, iron, zinc and vitamin $\mathrm{B}$ also it shows antimicrobial and anti-bacterial properties. (17).

4. Sesame seeds contain fixed oils, glycosides, fat, and carbohydrates useful in nutrition and to treat dryness.

5. Black grams are rich in protein, fat, starch, potassium which gives nourishment to plants.

6. Lentil decoction is rich in protein and helps in growth. (18)

In recent study of Kunap Jala A liquid organic manure: Preparation and its quality parameters done by Dr. Switu Jain in 2017 at Jamnagar shows Kunap Jala contains Nitrogen $0.37 \%$, Phosphorus $0.042 \%$, Potassium $0.050 \%$, Sulphur $123.61 \%$ and Iron $44.53 \mathrm{ppm}$ which is useful in growth, nourishment and treating plant diseases according to point of view ${ }^{(19)}$. So, our Aacharyas already had given this knowledge many years back how to prepare and used it.

Madhuyastyadi Kwath was used as second intervention to combat Pittaj diseases.

Madhuyastyadi Kwath shows following pharmcodynamic effects main contains are;
1. Yastimadhu (Glycyrrhiza glabra) which shows following properties Rasa Madhur, Virya Sheeta, Vipak Madhur, Guna Guru- Snigdha, Karma Tridoshahara (pacify all three aggravated Doshas), Rasyan (rejuvenating), Balavarnakrut (enhances strength, complexion).(20)

2. Madhuk (Madhuca indica) having following properties Rasa Madhur, Kashay, Virya Sheeta, Vipak Madhur, Guna Guru- Snigdha, Doshaghanta VataPitta Shamak, Karma Balya, Bruhana (improves strength). Due to excessive Pitta Dosha Ushanta (heat) increases also shows Pitavabhasta (yellowish discoloration) Balahani (loss of strength) so Yasthimadhu and Madhuk show exactly opposite properties of increased Pitta. Hence we can use Madhuyastyadi Kwath to treat Pittaj Vyadhi (diseases) of plant.(21)

Kunap Jala and Madhuyastyadi Kwath increased NPK, calcium and sulphur in plant tissue of Onion seedlings in optimum quantity the reason is still unknown. Excessive nutrient value and deficiency both leads to same problems so we have to provide everything in optimum level which can happen only due to Vrikshayurved method because our Aacharyas mentioned that very peculiarly.

\section{CONCLUSION}

Vrikshayurved intervention improved curling, dryness and yellowish discoloration of leaves significantly. It also doubled growth rate of the onion seedlings. It indicates that Vrikshayurved methods are applicable in today's era.

\section{ACKNOWLEDGEMENT}

I would like to thank my Dravyaguna Dept of SSAM, Hadapsar, Pune. I would also like to thank Directorate of Onion \& Garlic research centre, Rajgurunagar for guidance and allowing to performed study at research centre. I would also give the regards and thanks to Bhandarkar Oriental Research Institute, Shivaji nagar, Pune for maintaining old literature in good way and easy accessible for study purpose.

\section{REFERENCES}

1. Pandit Manohar Devkrushna, Prachin bharatiya vruksha ayrurveda, Shubhadasaraswat prakashan, pune, edition-2 2004, pg no-34.

2. Saxena RC, Choudhari SL, Nene YL, a textbook on ancient history of Indian agriculture, Asian AgriHistory Foundation (AAHF), Secunderabad, and Rajasthan chapter of AAHF, Udaipur, 2009, Chapter no-3, pg.no- 23.

3. Saxena RC, Choudhari SL, Nene YL, a textbook on ancient history of Indian agriculture, Asian agrihistory foundation (AAHF), Secunderabad, and Rajasthan chapter of AAHF, Udaipur,2009, Chapter no-15, pg.no- 98-99. 
More Shweta Vinod et al. Vrikshayurved Methods for Disease Control in Plants with Special Reference to Onion (Allium Cepa)

4. Dr.Gothankar Aparna, Nesari Tanuja, To study the Effect of Ashwagandha and Shatavari cultivated by modern method and method mentioned In Vrikshayurveda, shodhganga, 2010, pg.no-119. http://shodhganga.inflibnet.ac.in/handle/10603/2 15031

5. Dr. Pandey Gyanendra, Vrikshayurved of Surpala, Chaukhambha Sanskrit Series Office, Varanasi, Editon- First 2010, section -17,verse no-191, pg.64.

6. Dr. Pandey Gyanendra, Vrikshayurved of Surpala, Chaukhambha Sanskrit Series Office, Varanasi, Editon- First 2010, section 16, verse no 165-172, pg no 55-58.

7. Dr. Pandey Gyanendra, Vrikshayurved of Surpala, Chaukhambha Sanskrit Series Office, Varanasi, Editon- First 2010, section 17, verse no 185-192, pg no 62-65.

8. Qureshi AA, Lawande KE, Thangasamy A, Diagnosis and management of nutrient deficiency in Onion and Garlic, technical bulletin no.16, Directorate of onion and garlic research institute, 2011, pg.8-10.

9. https://www.ambius.com/learn/plantdoctor/why-plants-turn-yellow/

10. Qureshi AA, Lawande KE, Thangasamy A, Diagnosis and management of nutrient deficiency in Onion and Garlic, technical bulletin no.16, Directorate of onion and garlic research institute, 2011,pg.11-12.

11. https://plantophiles.com/plant-care/leavescurling-upwards/

12. Sharma Anant, Sushrut samhita, vol-1, chaukhamba surbharti prakashan, Varanasi, Chap no-41, verses no-8-9, pg.no-323.
13. Chunekar Krushana chandra, Bhavprakash nighantu, Chaukhamba bharati academy, Varanasi, reprint-2013, varga-10, 13, 21, 8pg.no-694, 742, 772, 630-639.

14. Sharma Priyavat, Charak samhita, Vol-1, chaukhamba Sanskrit pratishthan, Delhi, reprinted-2011, Chap.no-25, verse no-40, pg.337.

15. https://cookslarder.co.uk/blog/benefits-of-goatmeat/

16. Saxena RC, Choudhari SL, Nene YL, a textbook on ancient history of Indian agriculture, asian agrihistory foundation (AAHF), Secunderabad, and Rajasthan chapter of AAHF, Udaipur,2009,Chapter no-15, pg.no- 105.

17. Samarghandian S, Farkhondeh T, Samini F. Honey and Health: A Review of Recent Clinical Research. Pharmacognosy Research, 2017; Vol9(2), Pg.121-127.doi:10.4103/0974-8490. 204647.

18. https://www.hsph.harvard.edu/nutritionsource/f ood-features/lentils/

19. Jani.S, Prajapati.P.K, Harisha.C.R, Patel.B.R, Kunapjala a liquid organic manure: preparation and its quality parameters, World journal of pharmacy and pharmaceutical sciences, 2017, vol no- 6, 1989-2000(8), pg.no- 6.

20. Chunekar Krushanachandra, Bhavprakash nighantu, Chaukhamba bharati academy, Varanasi, reprint-2013, varga-1 pg.no-62.

21. Chunekar Krushanachandra, Bhavprakash nighantu, Chaukhamba bharati academy, Varanasi, reprint-2013, varga-6 pg.no-568.

\section{Cite this article as:}

More Shweta Vinod, Avalaskar Amit D, Mahajan Vijay, Sogam Onkar Anant. Vrikshayurved Methods for Disease Control in Plants With Special Reference to Onion (Allium Cepa). International Journal of Ayurveda and Pharma Research. 2021;9(8):9-15.

https://doi.org/10.47070/ijapr.v9i8.2041

Source of support: Nil, Conflict of interest: None Declared

\section{*Address for correspondence} Dr. More Shweta Vinod

P.G. Scholar,

Department of Dravyaguna vigyan,

Sumatibhai Shah Ayurved

Mahavidyalaya, Pune,

Maharashtra, India.

Contact: 917303858468

Email: shweta180695@gmail.com

Disclaimer: IJAPR is solely owned by Mahadev Publications - dedicated to publish quality research, while every effort has been taken to verify the accuracy of the content published in our Journal. IJAPR cannot accept any responsibility or liability for the articles content which are published. The views expressed in articles by our contributing authors are not necessarily those of IJAPR editor or editorial board members. 